\title{
Military Customs and Traditions / Militêre gewoontes en tradisies.
}

\section{Tattoo}

According to Boatner, the word probably originated among British troops in Holland during the Thirty Years War (1618 - 1648) or during the wars of King William III during the 1690's.

The word is derived from the Dutch 'tap' (tap or faucet) and 'toe' (to or off). When the time came for the soldiers to leave the taverns and return to their billets, the Officer of the Day, with a sergeant and drummer beat his way through the streets. This was the signal for the Dutch tavern keepers to 'Doe den tap toe' or turn off the taps.

Another theory expressed by Schulz in his book Wort und Brauchtum des Soldaten, maintains that the word comes from the seventeenth century German Army's 'Zapfenstreich' meaning 'bungli- ne' and having the same significance as 'tap toe'. The word itself however, came from the provosts' practice of drawing a chalk line across the bungs of the barrels during final evening check of the taverns. If this line was found to be tampered with, the inkeeper would be fined.

References to 'tap toe' go back as far as 1701 in the British Army. It is the signal to quiet down in barracks and to turn the lights off.

The word tattoo is also sometimes used in connection with military funerals: The Last Tattoo. The Tattoo is also sometimes elaborated with music and marching as entertainment, the recent Durban Military Tattoo being an excellent South African example.

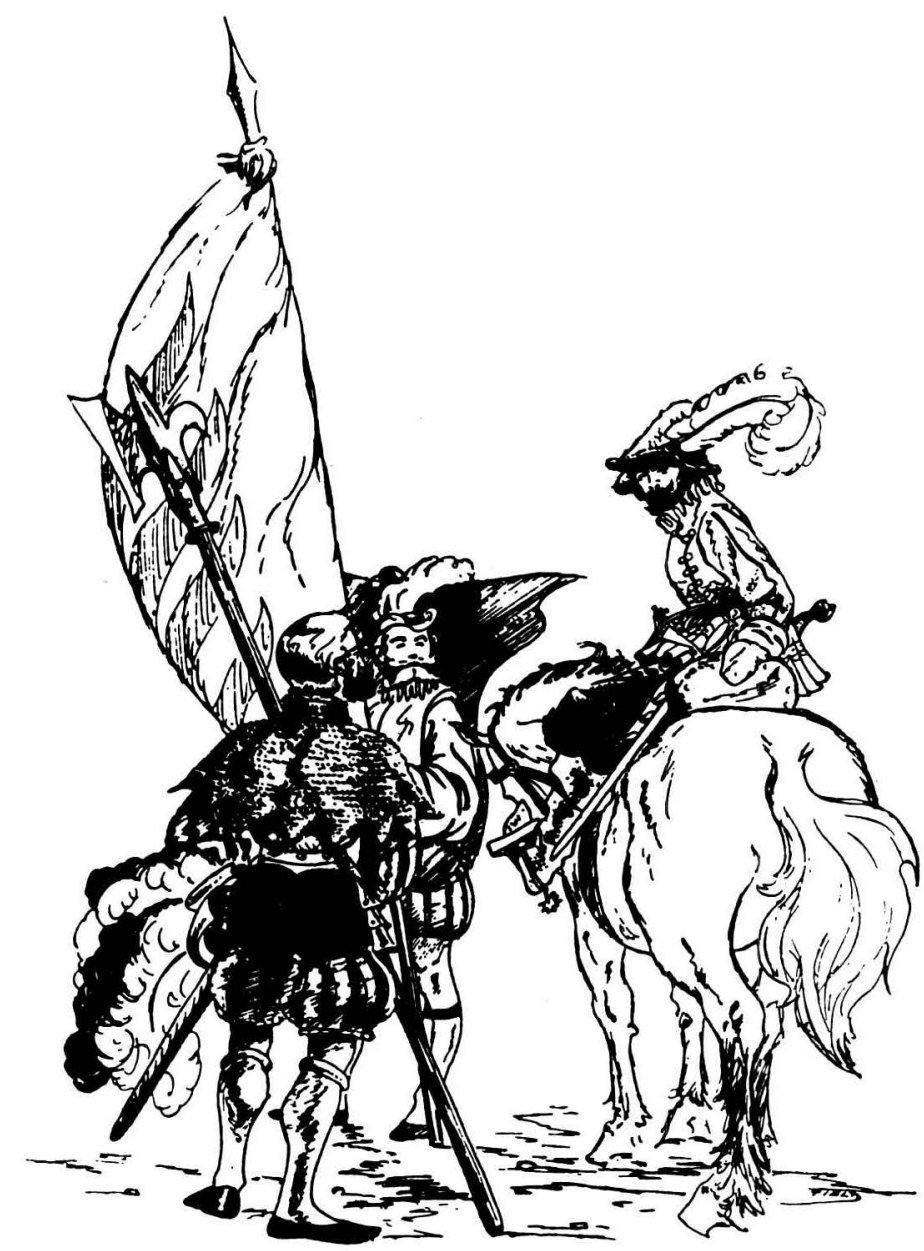

Landsknechte and Reiter, from whom most of our "modern" ideas of military organization stem. 


\section{Die Seremoniële koker en geskrif}

\section{Oorsprong}

Gedurende die middeleeue is òf op perkament (gemaak van lamwol) òf velyn (gemaak van kalfsvel) geskryf. Die onderkant van so ' $n$ vel is geperforeer sodat dit aanmekaar geheg kan word om 'n lang skrifrol te vorm. Andersins is dit ook aan die bokant geheg, soos sommige almanakke. By die boekrol is daar aan die bo en onderkant stokkies vasgeheg waaromheen die rol gedraai is. Sodoende is hanteerbaarheid aansienlik verhoog. Vandaar die naam boekrolle.

Hierdie rolle is in gekleurde silindervormige houers geberg en van 'n riem handvatsel voorsien sodat dit teen die muur opgehang kon word, soos 'n pylkoker. Om dokumente maklik te identifiseer is houers gekleur of van uitkenningstekens voorsien.

\section{MILITÊRE BOEKROLLE}

Middeleeuse militêre dokumente het hoofsaaklik kontraktuele verpligtinge tussen die staatshoof, sy militêre leiers en die soldate self behels.

Tegnologiese ontwikkeling het die boekrol in onbruik laat verval maar die belang van die eeue waarin boekrolle geskep is en in kokervormige houers bewaar is, het die mens bygebly - in so 'n mate dat die gebruik uit die argief opgediep is en in die huidige eeu die tradisionele manier om belangrike dokumente te bewaar, laat herleef het. Besondere geskrifte word vir oorhandiging in kunstig versierde kokers van edelmetaal geplaas en oorhandig. Genl J. C. Smuts het bv in sy leeftyd drie sulke silwer kokers ontvang; een van die Indiër-gemeenskap van Durban, een vanaf Israel en een vanaf die stad Edinburgh.

Die koker met geskrif dateer uit 'n ryk middeleeuse militêre verlede wat nie alleen op militêre kontraktuele gebied nie maar ook op die gebied van die godsdiens, wetenskap, handel en regspleging 'n rol gespeel het.

Wanneer die moderne weermagsmasjien in sy totaliteit in gedagte gehou word, is al hierdie vakrigtings in die huidige militêre lewe verteenwoordig. Die koker behels voorts die simboliek van 'n verbondenheid wat tussen die staat, militêre leiers en hulle ondergeskiktes bestaan.

Die moderne ekwivalent het in dié eeu 'n nuwe dimensie bygekry alwaar dit spesifiek aan individue gegee word om vertroue en eerbied oor te dra.

\section{The origin and significance of colours}

What is meant by the term 'Colour'? What is the significance of these unique flags which to the uninitiated might seem nothing more than 'moth-eaten rags on worm-eaten poles'?

Since the earliest recorded history of man it has been noticeable that there has always been some sort of device by which a group of individuals has sought to distinguish itself from other groups. These devices have most commonly taken the form of some sort of symbol or flag.

The type of flag from which Colours derived - i.e. made from some type of material affixed vertically to a pike or staff - was first used by the Chinese some 2600 years ago. Yet while the Egyptians, Greeks and Romans all used various symbols attached to poles for purposes of identification in warfare, it was only towards the end of the Middle Ages that the flag proper was introduced to Europe via the Middle East. The famous Bayeux Tapestry records some 30 different flags used in the Battle of Hasting's in 1066, although they do not seem to conform to any particular system.

These early flags were mainly used for purpose of identification. As the clothing and armour of mounted knights became more elaborate, it had become increasingly difficult to distinguish between friend and foe. A solution to this difficulty was provided by the design, according to fixed principles, of heraldic devices on flags, the flying or display of which would indicate the leaders' presence or headquarters. The flags were particularly useful in serving as rallying points for combatants in the chaos and confusion of medieval warfare.

Flags during this period were not only used to distinguish indidual leaders, but also to denote rank and nationality. It was at this stage, for instance, that the Cross of St George came to represent the English.

\section{Developments during the 16th century.}

It was not until the sixteenth century, however, that developments occurred from which latter-day Colours can realistically be traced. At this stage continental armies became more systematized in their organization. King Gustavus Adolphus of 
Sweden organized his army into troops, companies and regiments, each containing a fixed number of men, during the 30 years War. In early Prussia, too, there evolved companies of mercenary soldiers of about 300 men each called 'Landknechts.' These early Swedish and German companies and regiments each came to possess their own flag, while cavalry troops acquired smaller, lighter standards. The purpose of the flags was initially to enable each soldier to recognize his own company or regiment in the heat or battle.

In England too, similar developments were occurring, with individual companies and regiments adopting their own flags. And at this stage, too, the first references to the term 'Colour' can be traced in England. By the end of the sixteenth century according to Sir John Fortescue in his History of the British Army, 'the flags of infantry, from their diversity of hues, had gained the name of Colours'. ${ }^{1}$ Earlier Barrett had emphasized the point in his Therrike and Practike of Modern War.

In Britain, until the middle of the eighteenth century, there existed a great variety in types of Colours, with no set pattern governing the design and issue of Colours. In any one regiment the Colonel, the Lieutenant-Colonel, the Major, and the respective captains of the various companies, all had their own Colours. The devices on these Colours were usually variations of the Colonel's coat-of-arms. In addition to these regimental Colours, there were also Colours representing the nation and the souvereign.

In 1747, however, regulations were introduced which were to standardize the use of British infantry Colours. From that date it was forbidden for Colonels to put their personal coat-of-arms on the regimental Colours. More important, henceforth regiments of foot were to be allowed only two Colours

In 1844 further, definitive regulations governing British Army Colours appeared in Regulations and Orders for the Army, 1844, in which precise rules regarding the design and issue of the two Colours were laid out. With a few modifications it is these regulations which have governed the form and design of Colours in the Crown Colonies of the Cape and Natal prior to 1910, and subsequently in the Union of South Africa. ${ }^{6}$

\section{The question of king's colours in the union}

The Union Defence Force inherited almost in their entirety the traditions surrounding Colours from the British. The two Boer Republics which were incorporated into the Union of South Africa seem to have had no tradition of Colours as such. There are only two recorded instances of Boer Commando's possessing Colours, while two Commandant-Generals of the South African Republic (P. J. Joubert and L. Botha) were presented with banners somewhat akin to Colours in 1883 and 1900 respectively. ${ }^{7}$

From the start the whole question regarding the Kings Colour in South African military tradition was an anomalous one. It was never clear whether all units were entitled to King's or Queen's Colours, or whether the units had to wait until they were presented with one (the latter view seems to have prevailed). The whole controversy in fact dragged on inconclusively until it was abruptly terminated in 1961 when South Africa became a Republic. The parading of the Sovereign's Colours by SA units on or after that date would obviously have been inappropriate, and so instructions were issued by the AdjutantGeneral to the effect that all units in possession of Sovereign's Colours were to lay them up in suitable resting places prior to 31 May 1961.

\section{The proposal to introduce a state president's colour}

The matter might have rested there. Soon after SA had become a Republic, however, the SADF received a proposal from a Mr Harold Larsen suggesting that a State President's Colour be introduced to replace the Old Sovereign's Colour.

After due deliberation, the proposal was rejected by the SADF as the institution of a State President's Colour entirely separate from existing ceremonial provisions in the SADF does not seem justified.

The National Flag is the symbol representing the Nation and, as such, is venerated by all in peace and war, especially by the SADF as the defenders of the Nation. There should therefore be no other flag or insignia introduced that could in any way detract from the veneration and pride of place accorded to the National Flag.

The Regimental Colour, of which there are twenty-four in possession of SADF units, 
conveys the sentiments of esprit de corps and patriotism to a much greater extent than any other Colour ever could.

\section{Vredessabels}

Die gebruik van die gevesgdienste om elk 'n vredessabel uit te loof vir die eenheid wat jaarliks die grootste bydrae op humanitêre gebied gemaak het, het in 1799 al ontstaan.

Die verhaal word vertel hoe vlugtelinge van die Pelew Eilande vir 4 jaar van 1793 tot 1797 in Bombaai gestrand was sonder dat hulle enige verdienste gehad het. Gedurende dié tyd het luitenant Snook van die Bombaai Vloot uit sy karige salaris na hulle omgesien.

In 1797 is die vlugtelinge in sy sorg geplaas en met die skip van die Oos Indiese Kompanje, die Waverley, na Macao teruggestuur. Met hul aankoms daar het hy ' $n$ klein skip op regeringsonkoste gekoop om hulle terug na hul tuiste in die Filippyne te neem. Onderweg het hulle slegte weer ervaar en moes skuiling soek. Uiteindelik het hulle tog die Pelew Eilande veilig bereik en luitenant Snook het hulle aan hulle gesinne terugbesorg.

Hierdie daad van sorg is in 1799 erken en 'n swaard wat in Londen gemaak is, is deur die Oos Indiese Kompanjie asook die mede offisiere van It Snook aan hom oorhandig. Dié swaard wat 'n spesiale inskripsie gehad het, is in Maart 1965 aan die National Army Museum gegee. Met die aanvaarding van die swaard het Veldmaarskalk Burggraaf Slim gesê: Snook se daad kenmerk die hulp wat wêreldwyd in oorlogstyd, hongersnood en tydens rampe deur die militêr aan burgerlikes verleen word.

Wilkinson Sword, wat bekendheid verwerf het as die laaste swaardsmit in Brittanje, het drie sabels aan die SAW uitgeloof, een vir elk van die gevegsdienste, om as wisseltrofeë te dien vir eenhede wat uitstaande prestasies op humanitêre gebied behaal het. In 1978 het die Leër, Lugmag en Vloot die eerste vredessabels oorhandig. 